\title{
Effect of single- and double-layer cesarean section closure on residual myometrial thickness and isthmocele - a systematic review and meta-analysis
}

\section{Tek ve çift katmanlı sezaryen kapatmanın rezidüel miyometrial kalınlı ve istmosel üzerine etkisi - sistematik bir gözden geçirme ve meta-analiz}

\author{
(1) Greg J Marchand ${ }^{1}$, (1) Ahmed Masoud ${ }^{2}$, (1) Alexa King ${ }^{3}$, (1) Stacy Rutherl, (1) Giovanna Brazill,

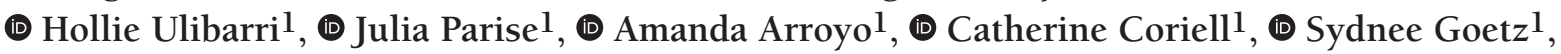 \\ (1) Ashley Christensen ${ }^{4}$, (1) Katelyn Sainz ${ }^{1}$
}

${ }^{1}$ Marchand Institute for Minimally Invasive Surgery, Mesa, Arizona, USA

${ }^{2}$ Fayoum University Faculty of Medicine, Fayoum, Egypt

3 International University of Health Sciences, Basseterre, St. Kitts

${ }^{4}$ Midwestern University College of Osteopathic Medicine, Glendale, Arizona, USA

\begin{abstract}
Objective: To determine the incidence of isthmocele, its effect on residual myometrial thickness (RMT), and other complications of Cesarean delivery (CD) in relation to single- and double-layer CD closure. We searched PubMed, SCOPUS, Web of Science, ClinicalTrials.gov, MEDLINE and Cochrane Library for relevant clinical trials assessing the use of single- and double-layer uterine closure in patients undergoing cesarean sections from inception through to March 2021.

Materials and Methods: Our population was women undergoing cesarean section with uterine closure by any double-layer method, compared with those undergoing uterine closure through a single-layer method. RMT (in $\mathrm{mm}$ ) was measured at 6 weeks, niche/isthmocele existence at 6 weeks, RMT (in mm) at 6-24 months and niche/isthmocele existence at 6-24 months. In order to present the highest quality evidence, we only included clinical trials in our analysis. To perform this review, we reported dichotomous outcomes using percent and total, while continuous outcomes were reported using mean \pm standard deviations, and relative $95 \%$ confidence intervals using the inverse variance method.

Results: We found that the RMT in the double-layer closure group was significantly higher at six weeks [mean difference (MD)=-0.43 (-0.77, -0.09$)$ ], $(\mathrm{p}=0.01)$ and at $6-24$ months of follow-up $[\mathrm{MD}=-1.27(-2.28,-0.25)],(\mathrm{p}=0.01)$. The incidence of isthmocele in the two groups, as well as the other investigated outcomes were similar across the different groups.

Conclusion: High-quality evidence shows that double-layer closure results in a higher RMT compared with a single-layer closure, despite no significant difference in isthmocele formation.

Keywords: Cesarean section closure, single-layer closure, double-layer closure, isthmocele cesarean section, cesarean scar defects

$\ddot{\mathrm{O} z}$

Amaç: Tek ve çift katmanlı sezaryen kapatma ile ilişkili olarak istmosel insidansının ve istmoselin rezidüel miyometrial kalınlık (RMT) ve diğer sezaryen komplikasyonları üzerindeki etkisinin değerlendirilmesi amaçlanmıștır. PubMed, SCOPUS, Web of Science, ClinicalTrials.gov, MEDLINE ve Cochrane Library'de, sezaryen ameliyatı geçiren hastalarda tek ve çift katmanlı uterus kapatmanın kullanımını değerlendiren klinik araştırmalar için bunların kullanılmaya başlanmasından Mart 2021'e kadarki süreçte arama yaptık.

Gereç ve Yöntemler: Bu çalışmada; sezaryen uygulanan ve herhangi bir tek katmanlı yöntemle uterusu kapatılan kadınlarla herhangi bir çift katmanlı yöntemle uterusu kapatılan kadınlar kıyaslandı. Ölçtüğümüz sonlanımlar arasında; 6. haftadaki rezidüel miyometrium kalınlığı (mm olarak), 6. haftadaki niş/istmosel varlığı, 6-24 aydaki rezidüel myometrium kalınlığı (mm olarak) ve 6-24 aydaki niş/istmosel varlığı yer almaktaydı. En yüksek kalitede kanıt sunmak için analizimize yalnızca klinik çalışmaları dahil ettik. Bu incelemeyi gerçekleştirmek için yüzde ve toplam kullanarak ikili sonlanımları analiz ettik. Sürekli sonlanımlar ise ters varyans yöntemi ile ortalama fark, standart sapma ve göreceli \%95 güven aralıkları kullanılarak değerlendirildi.
\end{abstract}

Address for Correspondence/Yazışma Adresi: Greg J Marchand MD, Marchand Institute for Minimally Invasive Surgery, Mesa, Arizona, USA Phone: +4809990905 E-mail: gm@marchandinstitute.org ORCID ID: orcid.org/0000-0003-4724-9148

Received/Geliş Tarihi: 11.10.2021 Accepted/Kabul Tarihi: 12.11.2021

${ }^{\circledR}$ Copyright 2021 by Turkish Society of Obstetrics and Gynecology

Turkish Journal of Obstetrics and Gynecology published by Galenos Publishing House 
Bulgular: Çift katmanlı kapama grubundaki RMT'nin 6. haftada [MD=-0,43 (-0,77, -0,09)], (p=0,01) ve 6 ila 24 aylık takipte anlamlı olarak daha yüksek olduğunu bulduk ( $\mathrm{MD}=-1,27[-2,28,-0,25])$, ( $\mathrm{p}=0,01)$. İstmosel insidansı ve araştırılan diğer sonlanımların herhangi biri açısından iki grup arasında hiçbir fark görülmedi.

Sonuç: Yüksek kaliteli kanıtlar, çift katmanlı kapatmanın, tek katmanlı kapatmaya kıyasla daha yüksek RMT ile sonuçlandığını gösterirken, istmosel oluşumu açısından anlamlı bir fark yok gibi görünmektedir.

Anahtar Kelimeler: Sezaryen kapatma, tek katman kapatma, çift katman kapatma, isthmosel, sezaryen, sezaryen skar defektleri

\section{Introduction}

Cesarean delivery (CD) accounts for 38\% of total deliveries worldwide, with an expected increase in the future $e^{(1,2)}$. Although CD can often be an unavoidably life-saving option for neonates, it is known to cause a variety of short- and longterm complications ${ }^{(3,4)}$. The short-term complications include abnormal uterine bleeding, pain, infection, and thromboembolic complications. Long-term complications include complicated future pregnancies, including the risk of uterine scar dehiscence and rupture, pathology involving placental adherence to the scar (accreta and percreta), and incidence of ectopic pregnancy within the scar ${ }^{(3-5)}$. Several authors have recently investigated the connection of two specific complications of $\mathrm{CD}$, namely isthmocele formation and a reduced residual myometrial thickness (RMT) in the area of the uterine scar, and their relationship with serious complications such as uterine scar dehiscence and uterine rupture in future pregnancies. Isthmocele formation has also been associated with pelvic pain and abnormal uterine bleeding in the non-pregnant state $e^{(5)}$.

The "isthmocele," was first described by Hugh Morris in $1995^{(6)}$, and refers to the scar due to a CD as visualized on a sagittal plane ultrasound. The isthmocele is often referred to as a "niche" because of the predictably triangular shape of the defect in the uterine myometrium, resembling a pouch on the anterior wall of the uterine isthmus ${ }^{(7)}$. This finding is a result of myometrial discontinuation or thinning at the site of the previous incision ${ }^{(8)}$. At time of ultrasonography, an isthmocele appears as a triangular anechoic area at the site of the incision and may best be visualized by saline contrast hysterosonography ${ }^{(7,9)}$. Several authors have attempted to classify the severity of an isthmocele. Many have done so by measuring the reduction in wall thickness or according to the residual (or remaining) myometrial thickness (RMT) at the site of the scar. Authors have also postulated that measurements of the RMT may have predictive value in regards to the risk of uterine rupture during delivery in patients with previous $C D^{(10,11)}$. This postulation holds that a lower RMT may indicate a weaker uterine scar, and thus a higher likelihood of uterine rupture or dehiscence with subsequent pregnancies ${ }^{(11,12)}$.

There are no clear findings as to how often $C D$ results in the formation of an isthmocele, nor which CD closures are most at risk for this phenomenon ${ }^{(9)}$. It is possible that this incidence would depend largely on the method used to assess uterine thickness ${ }^{(10)}$. Despite this, most authors agree that the prevalence of isthmocele is on the rise ${ }^{(11-13)}$. Furthermore, several authors have linked risk factors to its occurrence ${ }^{(3)}$. These include multiple CDs as the major risk factor, duration of labor (prior to $C D$ ) and the position of the incision (lower uterine segment or contractile portion) on the uterus ${ }^{(14)}$.

The incidence of isthmocele is becoming a serious issue and many authors have suggested an increased incidence of serious complications of pregnancy following the development of an isthmocele ${ }^{(12,15)}$. In addition to uterine rupture, authors have described an isthmocele as being related to the development of placenta previa, accreta, scar dehiscence, and ectopic pregnancy ${ }^{(12,15,16)}$.

Recently, many authors have postulated that the closure technique at the time of $\mathrm{CD}$ play a key role in the development of an isthmocele ${ }^{(17-19)}$. The assumption is that different techniques may affect the healing of the scar and result in different RMT values. These include techniques resulting in the physical approximation of less tissue, as well as in irregularities in the closure, leading to the development of the isthmocele ${ }^{(19)}$. As closure techniques vary from institute to institute as well as from surgeon to surgeon, there is no consensus of the superiority of one technique over others. Several authors, however, demonstrated that a single-layer closure may result in a higher incidence of isthmocele formation, when compared with double-layer techniques ${ }^{(19,20)}$.

This lack of consensus has led us to focus on the comparison between different closure techniques in the formation of the isthmocele and its possible pathologic sequelae. Thus, we sought to investigate this phenomenon, with the possibility that high-quality evidence may exist to aid in the decision of which $\mathrm{CD}$ closure method may be able to prevent the incidence of isthmocele, and possible sequelae.

In this systematic review and meta-analysis, we aimed at assessing the correlation between sonographic characteristics of an isthmocele (especially RMT) and the incidence of maternal complications, especially uterine rupture. We further sought to analyze if the choice of $\mathrm{CD}$ closure technique (specifically singleor double-layer closure) affects the formation of isthmocele and the possible maternal complications.

\section{Methods}

This meta-analysis was performed following the Preferred Reporting Items for Systematic Reviews and Meta-Analyses (PRISMA)(21) and the guidelines reported in the Cochrane Handbook for Systematic Reviews of Interventions ${ }^{(22)}$.

\section{Literature Search}

We searched six databases: Web of Science, SCOPUS, Cochrane CENTRAL, ClinicalTrials.Gov, MEDLINE and PubMed, from 
inception until March 2021. We adopted the following search strategy with no restrictions on date of publication or language: [(double-layer far-far-near-near) OR (FFNN) OR (single-layer continuous locked) OR (SLL) OR (continuous single-layer unlocked) OR (continuous locked single-layer) OR (doublelayer sutures)] AND [(isthmocele) OR (cesarean scar defect) OR (uterine scar deficiency) OR (uterine niche) OR (uterine pouch) OR (cesarean)].

\section{Eligibility Criteria}

We included all the studies that met the following criteria: (i) Population: women undergoing cesarean section, (ii) Intervention: uterine closure by any double-layer closure, (iii) comparator: uterine closure by any single-layer closure, (iv) Outcomes: the primary outcome was RMT (in mm) at 6 weeks, niche/isthmocele existence at 6 weeks, RMT (in mm) at 6-24 months and niche/isthmocele existence at 6-24 months. Other outcomes included the number of patients needing additional sutures, estimated number of additional suture throws required, blood loss $(\mathrm{mL})$, change in hemoglobin or hematocrit level, postoperative hemoglobin or hematocrit value, maternal infectious morbidity, postpartum fever, number of patients needing a blood transfusion, and the incidence of postoperative endometritis. (v) Study design: we included only clinical trials. Our exclusion criteria were: (1) uncontrolled clinical trials, (2) studies that did not report data or measures for our selected outcomes, or (3) studies with no available full text.

\section{Screening of Results}

We exported the results of the search using Endnote X8.0.1 (Build 1044), with the removal of duplicates performed automatically by the software. After that we screened the studies manually in two steps, title and abstract screening followed by a full text screening.

\section{Data extraction and Analysis}

After screening, we extracted the data from the selected studies and categorized it into three main groups:

1) Baseline and demographic data of patients in each study, including age (in years), incidence of nulliparity, gestational age at $\mathrm{CD}$ (in weeks), BMI (in $\mathrm{kg} / \mathrm{m}^{2}$ ), preterm delivery, prior cesarean deliveries and operative time (in minutes).

2) Data for analysis including outcome values of RMT (in mm) at 6 weeks, niche/isthmocele existence at 6 weeks, RMT (in $\mathrm{mm}$ ) at 6-24 months, niche prevalence at 6-24 months, number of patients needing additional sutures, estimated number of additional suture throws required, blood loss $(\mathrm{mL})$, change of hemoglobin level, hematocrit value, maternal infectious morbidity, postpartum fever, number of patients needing a blood transfusion and incidence of postoperative endometritis. In addition to the previous two categories, we extracted the data required to assess the risk of bias using the seven domains according to Cochrane's risk of bias tools ${ }^{(23)}$.

\section{Data Analysis}

We used Review Manager Software (RevMan 5.4.1) to analyze the data. We analyzed dichotomous outcomes using percent and total, while continuous outcomes were displayed through the mean difference (MD), standard deviations (SD), and relative $95 \%$ confidence intervals using the inverse variance method. The two tests used to measure inconsistency among the studies were the I-squared test $\left(\mathrm{I}^{2}\right)$ and the $\mathrm{p}$-value of chi-square test. In accordance with recommendations from the Cochrane Handbook, outcomes with $\mathrm{I}^{2}>50 \%, \mathrm{p}<0.1$ were considered heterogeneous, while outcomes with $1^{2}<50 \%, p>0.1$ were considered homogeneous ${ }^{(23)}$. Homogenous data were analyzed using a fixed-effect model, while heterogeneous outcomes were analyzed using the random-effect model.

\section{Quality Assessment}

We evaluated the quality of this systematic review and metaanalysis using the Grading of Recommendations Assessment, Development and Evaluation (GRADE) guidelines. According to the Cochrane risk of bias (ROB) tool for clinical trials, we performed the ROB assessment for all included studies according to the following categories: 1) proper randomization, 2) blind allocation of the included patients into each group, 3) blinding of patients only (single-blinding), blinding of both personnel and participants (double-blinding), or a complete lack of blinding, 4) Attrition bias, 5) Selection bias 6) Assessor's awareness of the outcome (blinded or not), 7) Other bias. Using these categories, we also assessed the total ROB for all included studies using the same tool.

\section{Results}

\section{Summary of Included Studies}

Supplementary Figure S1 shows a PRISMA flow diagram of our literature search. In our study, we performed an analysis of 8799 patients from twenty studies ${ }^{(18,23-42)}$. A total of 4406 patients experienced a single-layer closure for their cesarean section, and 4393 patients experience a double-layer closure. The mean age of the single-layer closure group was $29.1 \pm 4.7$ years, while that of the double-layer closure group was $29.09 \pm 5.05$ years. Table 1 show a detailed summary of the included participants, including their demographic data, incidence of nulliparity, gestational age at CD (in weeks), BMI (in $\mathrm{kg} / \mathrm{m}^{2}$ ), incidence of preterm delivery, number of prior $\mathrm{CD}$, and incidence of multiple births.

\section{Results of Risk of Bias Assessment}

The result of the ROB assessments yielded an overall low $\mathrm{ROB}$, according to Cochrane's tool. Following randomization, all studies were at low risk of randomization, except for Hayakawa et al. ${ }^{(18)}$, whose is trial was not randomized. As for the allocation concealment, all studies reported adequate allocation concealment; therefore, they were judged as a low ROB, except Hayakawa et al. ${ }^{(18)}$ and Batioğlu et al. ${ }^{(30)}$, which 


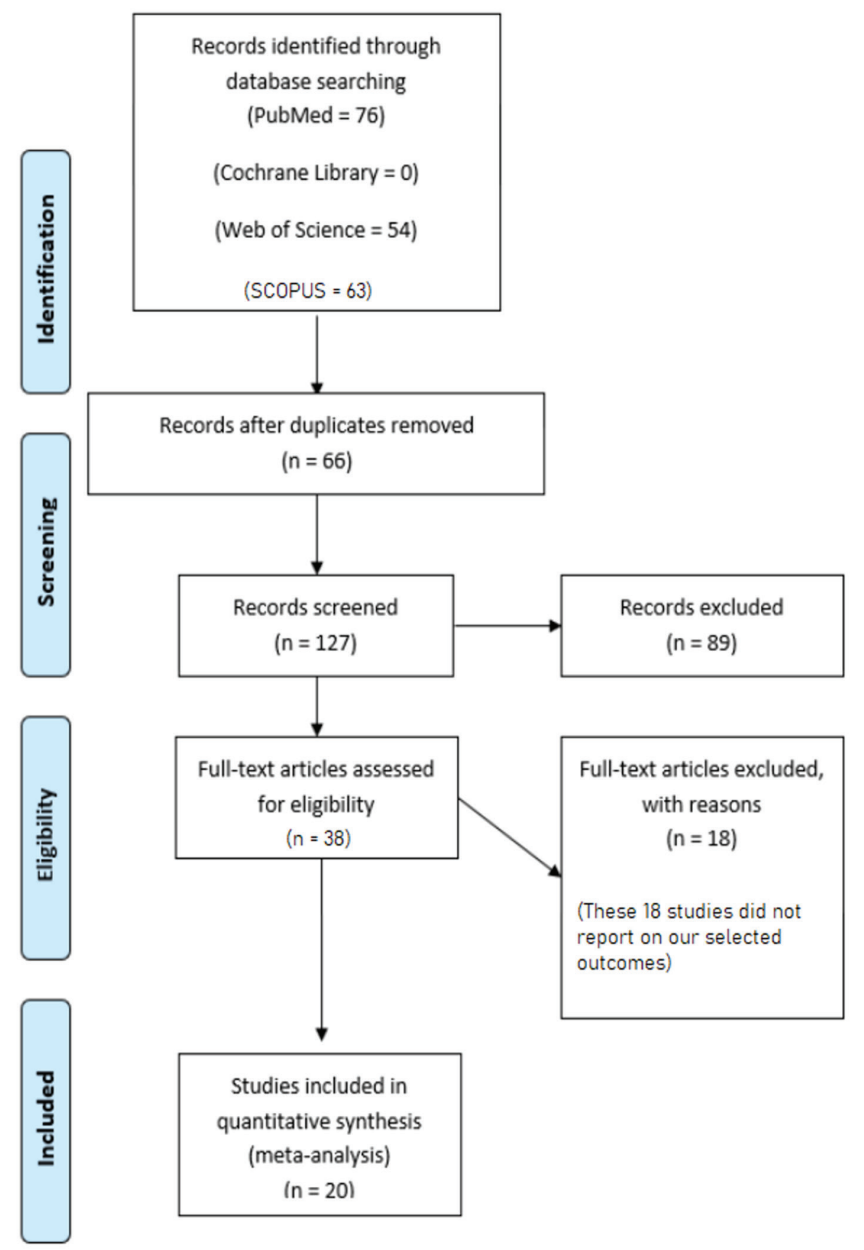

Supplementary Figure S1. The PRISMA flow diagram of our literature search

reported inadequate allocation concealment. The majority of the included studies were blinded, with the exception of three studies ${ }^{(27,30,36)}$ that did not report enough data about blinding of the participants and personnel. As a result, these three studies were judged to be at an unclear ROB, and three additional studies $^{(18,31,35)}$ were not blinded at all. All studies were at high $\mathrm{ROB}$ with regards to the blinding of the assessors with the exception of five studies ${ }^{(34,33,35,40,41)}$ that had insufficient data, and five studies ${ }^{(27,29,36,39,42)}$ that were judged to be low risk. The remaining domains of the Cochrane tool were all at low $\mathrm{ROB}$, except four studies ${ }^{(30-33,37)}$ found to be at high risk of attrition bias, and one study ${ }^{(28)}$ that showed unclear data in the category of selective reporting. A summarized illustration of the risk of the assessed bias of the included trials is found in Supplementary Figures S2A and S2B. Supplementary Table S1 shows the detailed ROB assessment.

\section{Patients Needing Additional Suturing:}

Seven studies demonstrated patients requiring additional suturing as an outcome $e^{(33,36,37,39,41-43,45)}$ and showed that there was no significant difference between the two groups [RR $=1.02$

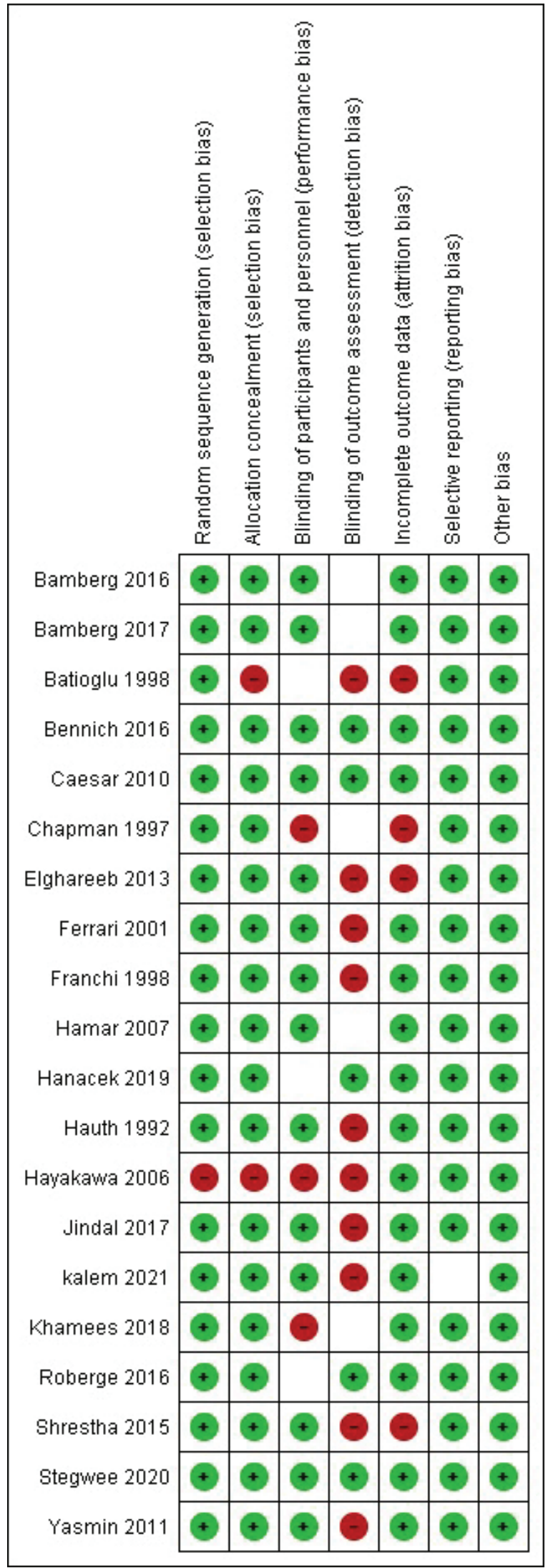

Supplementary Figure S2B. Results of our assessment of bias of the included studies 
Table 1. Detailed summary of the included participants and their demographic data

\begin{tabular}{|c|c|c|c|c|c|c|c|c|}
\hline \multirow{2}{*}{ Study ID } & \multicolumn{2}{|c|}{ Sample size, $\mathbf{n}$} & \multicolumn{2}{|c|}{ Age (years), mean (SD) } & \multicolumn{2}{|c|}{ Nulliparity, n (\%) } & \multicolumn{2}{|c|}{$\begin{array}{l}\text { Gestational age at cesarean } \\
\text { (weeks), mean (SD) }\end{array}$} \\
\hline & Single & Double & Single & Double & Single & Double & Single & Double \\
\hline Jindal 2016 & 27 & 27 & $30.8(4)$ & $31.1(6.4)$ & $22(80.8)$ & $20(74.1)$ & $39.2(0.6)$ & $39.1(0.5)$ \\
\hline Jindal 2017 & 157 & 129 & $31.9(5.7)$ & $30.3(6.5)$ & $59(37)$ & $48(37)$ & $37.6(2.4)$ & $37.3(2.3)$ \\
\hline Bennich 2016 & 35 & 38 & $30.3(4.5)$ & $30.5(5.5)$ & $\mathrm{nr}$ & $\mathrm{nr}$ & $38.7(0.6)$ & $38.9(0.7)$ \\
\hline Jindal 2001 & 83 & 75 & $31.7(4.8)$ & $30.7(4.8)$ & $\mathrm{nr}$ & $\mathrm{nr}$ & $38.3(1.54)$ & $38.2(2.1)$ \\
\hline Franchi 1998 & 149 & 150 & $29.5(5.1)$ & $30.6(4.7)$ & $83(55.7)$ & $77(51.3)$ & $36.7(2.8)$ & $37(2.4)$ \\
\hline Hanacek 2019 & 149 & 175 & $31.3(3.7)$ & $31.7(3.7)$ & $\mathrm{nr}$ & $\mathrm{nr}$ & $40(1.5)$ & $40.3(0.7)$ \\
\hline Hayakawa 2006 & 50 & 51 & $31.1(5)$ & $31.4(5.5)$ & $\mathrm{nr}$ & $\mathrm{nr}$ & $36.9(2.6)$ & $36.6(3.1)$ \\
\hline Kalem 2021 & 68 & 70 & $29.25(6.27)$ & $28.94(5.17)$ & $\mathrm{nr}$ & $\mathrm{nr}$ & $38.50(2.7)$ & $39.40(3.6)$ \\
\hline Caesar 2010 & 1438 & 1496 & $30.6(5.9)$ & $30.6(5.9)$ & $989(67)$ & $1027(69)$ & $39(2)$ & $39.1(1.9)$ \\
\hline Jindal 2011 & 30 & 30 & $\mathrm{nr}$ & $\mathrm{nr}$ & $\mathrm{nr}$ & $\mathrm{nr}$ & $\mathrm{nr}$ & $\mathrm{nr}$ \\
\hline Jindal 2016 & 157 & 129 & $31.9(5.7)$ & $30.3(6.5)$ & $59(37)$ & $48(37)$ & $37.6(2.4)$ & $37.3(2.3)$ \\
\hline Stegwee 2020 & 1144 & 1148 & $32(4.7)$ & $32.1(4.6)$ & $764(76.3)$ & $764(76.2)$ & $38.9(1.3)$ & $38.9(1.3)$ \\
\hline Khamees 2018 & 26 & 12 & $\mathrm{nr}$ & $\mathrm{nr}$ & $\mathrm{nr}$ & $\mathrm{nr}$ & $\mathrm{nr}$ & $\mathrm{nr}$ \\
\hline Jindal 2017 & 188 & 169 & 23.2 & 24.5 & $\mathrm{nr}$ & $\mathrm{nr}$ & $38.1(1.5)$ & $37.8(1.8)$ \\
\hline Shrestha 2015 & 25 & 25 & $26.04(5.06)$ & $23.92(4.32)$ & $21(84)$ & $17(68)$ & $38.36(2.21)$ & $38.92(1.35)$ \\
\hline Elghareeb 2013 & 75 & 75 & $28.84(3.4)$ & $28.36(3.2)$ & $\mathrm{nr}$ & $\mathrm{nr}$ & $39.11(0.7)$ & $39.16(0.7)$ \\
\hline Batioglu 1998 & 63 & 55 & $28(4)$ & $30(4.2)$ & $\mathrm{nr}$ & $\mathrm{nr}$ & $40(1.2)$ & $39(1.3)$ \\
\hline Hamar 2007 & 15 & 15 & $30(7)$ & $25(7)$ & $11(73)$ & $8(53)$ & $39.3(0.5)$ & $38.6(0.9)$ \\
\hline Chapman 1997 & 70 & 75 & 24 & $\mathrm{nr}$ & $\mathrm{nr}$ & $\mathrm{nr}$ & $39(3.7)$ & $37(5.2)$ \\
\hline Hauth 1992 & 457 & 449 & 24.2 & 24.6 & $\mathrm{nr}$ & $\mathrm{nr}$ & 38 & 37.8 \\
\hline \multirow{2}{*}{ Study ID } & \multicolumn{2}{|c|}{ BMI, kg/m², mean (SD) } & \multicolumn{2}{|c|}{ Preterm delivery, n (\%) } & \multicolumn{2}{|c|}{ Prior cesarean deliveries, $\mathrm{n}(\%)$} & \multicolumn{2}{|c|}{ Operative time (minutes) } \\
\hline & Single & Double & Single & Double & Single & Double & Single & Double \\
\hline Jindal 2016 & $25.1(4.7)$ & $23.5(3.9)$ & $\mathrm{nr}$ & $\mathrm{nr}$ & $\mathrm{nr}$ & $\mathrm{nr}$ & $25.1(4.7)$ & $23.5(3.9)$ \\
\hline Jindal 2017 & $24.5(4.9)$ & $25.6(6.2)$ & $38(24)$ & 25 (19) & $66(42)$ & $57(44)$ & $\mathrm{nr}$ & $\mathrm{nr}$ \\
\hline Bennich 2016 & $24.6(4.8)$ & $24.1(3.5)$ & $\mathrm{nr}$ & $\mathrm{nr}$ & $\mathrm{nr}$ & $\mathrm{nr}$ & $23.7(4.7)$ & $25.3(4.2)$ \\
\hline Jindal 2001 & $22.81(4)$ & $21.85(4)$ & $\mathrm{nr}$ & $\mathrm{nr}$ & $\mathrm{nr}$ & $\mathrm{nr}$ & $31.6(1.38)$ & $44.4(1.44)$ \\
\hline Franchi 1998 & $\mathrm{Nr}$ & $\mathrm{nr}$ & $57(38.3)$ & $48(32)$ & $23(15.4)$ & $18(12)$ & $33.75(13.75)$ & $52.5(22.5)$ \\
\hline Hanacek 2019 & $22.7(3.6)$ & $22.2(3)$ & $\mathrm{nr}$ & $\mathrm{nr}$ & $\mathrm{nr}$ & $\mathrm{nr}$ & $\mathrm{nr}$ & $\mathrm{nr}$ \\
\hline Hayakawa 2006 & $26.2(3.9)$ & $26.2(3.9)$ & $\mathrm{nr}$ & $\mathrm{nr}$ & $\mathrm{nr}$ & $\mathrm{nr}$ & $\mathrm{nr}$ & $\mathrm{nr}$ \\
\hline Kalem 2021 & $26.04(2.37)$ & $25.90(2.28)$ & $\mathrm{nr}$ & $\mathrm{nr}$ & $\mathrm{nr}$ & $\mathrm{nr}$ & $36.91(6.2)$ & $35.71(7.7)$ \\
\hline Caesar 2010 & $\mathrm{Nr}$ & $\mathrm{nr}$ & $\mathrm{nr}$ & $\mathrm{nr}$ & $\mathrm{nr}$ & $\mathrm{nr}$ & $36.2(11.6)$ & $38.3(11.8)$ \\
\hline Jindal 2011 & $\mathrm{Nr}$ & $\mathrm{nr}$ & $\mathrm{nr}$ & $\mathrm{nr}$ & $\mathrm{nr}$ & $\mathrm{nr}$ & $40.06(2.98)$ & $41.07(3.8)$ \\
\hline Jindal 2016 & $24.5(4.9)$ & $25.6(6.2)$ & $38(24)$ & 25 (19) & $66(42)$ & $57(44)$ & 35.8 & $36.1(10)$ \\
\hline Stegwee 2020 & $26.4(4.6)$ & $26.6(4.8)$ & $133(13.2)$ & $142(14)$ & $\mathrm{nr}$ & $\mathrm{nr}$ & $38.9(11.7)$ & $42.8(11.2)$ \\
\hline Khamees 2018 & $\mathrm{Nr}$ & $\mathrm{nr}$ & $\mathrm{nr}$ & $\mathrm{nr}$ & $\mathrm{nr}$ & $\mathrm{nr}$ & $33.2(3.1)$ & $37.8(3.4)$ \\
\hline Jindal 2017 & $\mathrm{Nr}$ & $\mathrm{nr}$ & $\mathrm{nr}$ & $\mathrm{nr}$ & $\mathrm{nr}$ & $\mathrm{nr}$ & $51.4(6.3)$ & $52.6(4.5)$ \\
\hline Shrestha 2015 & $\mathrm{Nr}$ & $\mathrm{nr}$ & $\mathrm{nr}$ & $\mathrm{nr}$ & $\mathrm{nr}$ & $\mathrm{nr}$ & $\mathrm{nr}$ & $\mathrm{nr}$ \\
\hline Elghareeb 2013 & $\mathrm{Nr}$ & $\mathrm{nr}$ & $\mathrm{nr}$ & $\mathrm{nr}$ & $\mathrm{nr}$ & $\mathrm{nr}$ & $43.86(7.1)$ & $47.7(5.9)$ \\
\hline Batioglu 1998 & $\mathrm{Nr}$ & $\mathrm{nr}$ & $\mathrm{nr}$ & $\mathrm{nr}$ & $7(11.1)$ & $6(10.9)$ & $36.54(16.15)$ & $39(17.3)$ \\
\hline Hamar 2007 & $\mathrm{Nr}$ & $\mathrm{nr}$ & $\mathrm{nr}$ & $\mathrm{nr}$ & $\mathrm{nr}$ & $\mathrm{nr}$ & $55(15)$ & $58(12)$ \\
\hline Chapman 1997 & $\mathrm{Nr}$ & $\mathrm{nr}$ & $9(14)$ & $19(25)$ & $\mathrm{nr}$ & $\mathrm{nr}$ & $\mathrm{nr}$ & $\mathrm{nr}$ \\
\hline Hauth 1992 & $\mathrm{Nr}$ & $\mathrm{nr}$ & $139(30)$ & $137(30)$ & $126(28)$ & $99(22)$ & 43.8 & 47.5 \\
\hline
\end{tabular}

BMI: Body mass index, Kg: Kilograms, M: Meters, NR: Not reported 
$(0.95,1.11)],(p=0.58)$. The pooled analysis was homogeneous $(\mathrm{p}=0.16) ; \mathrm{I}^{2}=36 \%$, as seen in Figure 1 .

\section{Number of Additional Suture Throws Required:}

Only three studies ${ }^{(28,39,42)}$ reported the number of additional suture throws required as an outcome. Their overall MD was similar across the two groups $[\mathrm{MD}=-0.77(-2.45,0.91)]$, $(\mathrm{p}=0.37)$. The pooled analysis was heterogeneous $(\mathrm{p}=0.01)$; $\mathrm{I}^{2}=99 \%$ as seen in Figure 2 . We resolved the heterogeneity by the exclusion of one of the studies (Ferraria et al. $)^{(25)}(\mathrm{p}=0.7)$; $\mathrm{I}^{2}=0 \%$. The pooled analysis after this exclusion showed no significant difference between the two groups $[\mathrm{MD}=0.00(-0.06$, $0.06)$ ], $(p=0.9)$ also seen in Figure 2.

\section{Blood Loss (in $\mathrm{mL}$ ):}

Ten studies $(21,27,28,36,38,39,41-43,45)$ reported blood loss outcomes. Their overall MD was similar across the two groups [MD= $-12.56(-47.06,21.94)],(p=0.48)$. The pooled analysis was heterogeneous ( $\left.\mathrm{p}=0.01 ; \mathrm{I}^{2}=84 \%\right)$ as seen in Figure 3. We could not resolve the heterogeneity by subgroup analysis or the "leave-one-out" method.

\section{Change in Hemoglobin Level:}

Three studies ${ }^{(28,29,31)}$ reported data on the change in hemoglobin level. Their overall MD was similar across the two groups $[\mathrm{MD}=0.03(-0.11,0.17)],(\mathrm{p}=0.65)$. The pooled analysis was homogeneous $(\mathrm{p}=0.42) ; \mathrm{I}^{2}=0 \%$, as seen in Figure 4 .

\section{Hematocrit:}

Three studies ${ }^{(28,33,36)}$ reported the postoperative hematocrit level as an outcome. Their overall mean difference was similar between the two groups $[\mathrm{MD}=-0.07(-0.98,0.85)],(\mathrm{p}=0.89)$.

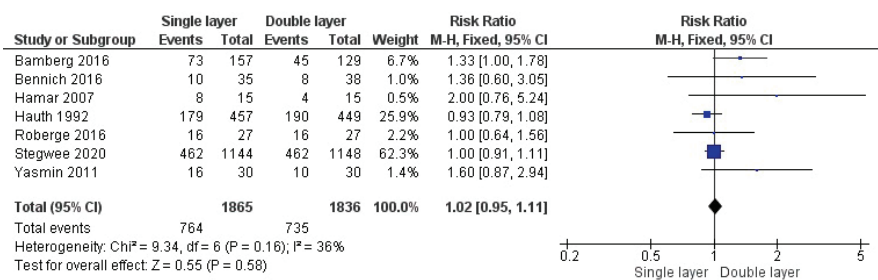

Figure 1. Analysis of the outcome of patients needing additional suturing

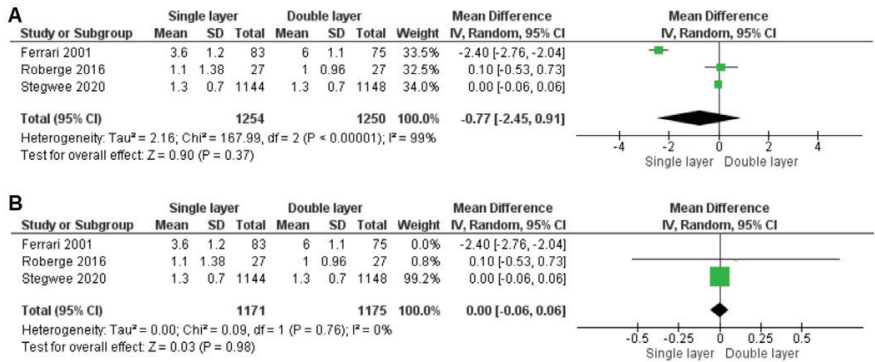

Figure 2A. Analysis of the outcome of the number of additional suture throws required. $2 \mathrm{~B}$. Analysis of the outcome of the number of additional suture throws required, but after excluding one study to solve heterogeneity
The pooled analysis was homogeneous ( $\mathrm{p}=0.98) ; \mathrm{I}^{2}=0 \%$, as seen in Figure 5.

\section{Maternal Infectious Morbidity:}

Maternal infectious morbidity was reported as an outcome by four studies ${ }^{(27,32,34,36)}$. The overall risk ratio showed that there was no significant difference in maternal infectious morbidity between the two groups $[R R=1.00[0.86,1.16)],(p=0.96)$. The pooled analysis was homogeneous $(\mathrm{p}=0.5) ; \mathrm{I}^{2}=0 \%$, as seen in Supplementary Figure S3.

\section{Postpartum Fever:}

Postpartum fever was reported as an outcome by seven studies $^{(21,27-29,32,33,43)}$. The overall risk ratio showed no significant difference in postpartum fever between the two groups $[R R=0.77(0.54,1.08)],(p=0.13)$. The pooled analysis was homogeneous $(\mathrm{p}=0.31) ; \mathrm{I}^{2}=15 \%$, as seen in Supplementary Figure S4.

\section{Number of Patients Requiring Transfusion:}

Six studies $(27,29,32,34,37,43)$ reported the number of patients requiring blood transfusion as an outcome. The overall risk ratio showed that there was no significant difference in this outcome between the two groups $[R R=0.96(0.69,1.32)],(p=0.78)$. The pooled analysis was homogeneous ( $\mathrm{p}=0.83) ; \mathrm{I}^{2}=0 \%$, as seen in Supplementary Figure S5.

\section{Postpartum Endometritis:}

Five studies $27,29,32-34,37,43)$ demonstrated the incidence of postoperative endometritis as an outcome. The overall risk ratio showed that this outcome was not significantly different between the two groups $[R R=1.15(0.93,1.43)],(p=0.19)$. The pooled analysis was homogeneous $(\mathrm{p}=0.85) ; \mathrm{I}^{2}=0 \%$, as seen in supplementary Figure S6.

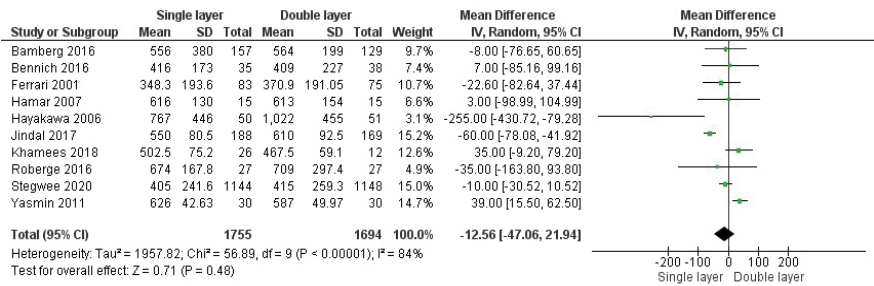

Figure 3. Analysis of the outcome of total blood loss

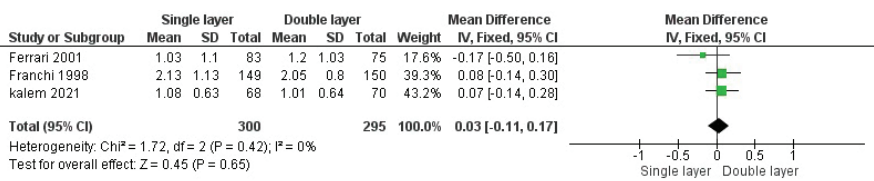

Figure 4. Analysis of the outcome of change of hemoglobin level

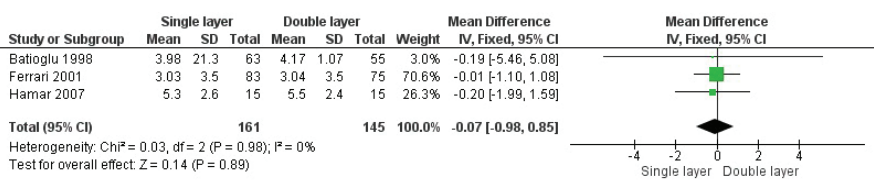

Figure 5. Analysis of the outcome of postoperative hematocrit 


\section{RMT (in mm) at 6 Weeks:}

Nine studies ${ }^{(35,36,38-40,42-45)}$ reported the RMT (in mm) at 6 weeks as an outcome. The overall mean difference showed that there

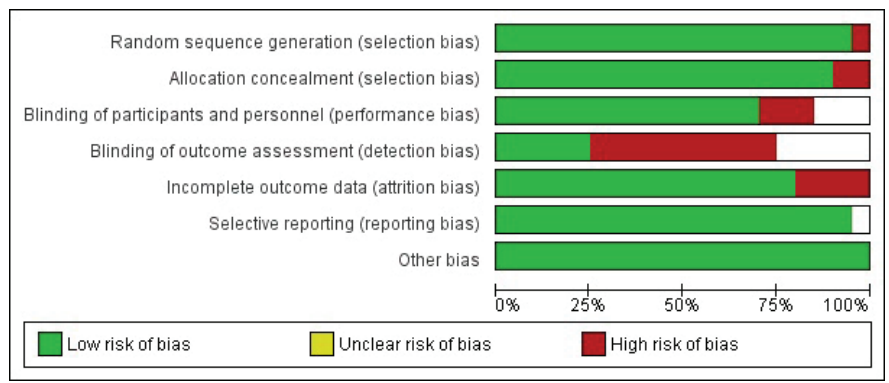

Supplementary Figure S2A. Graphical representation of the risk of bias assessment

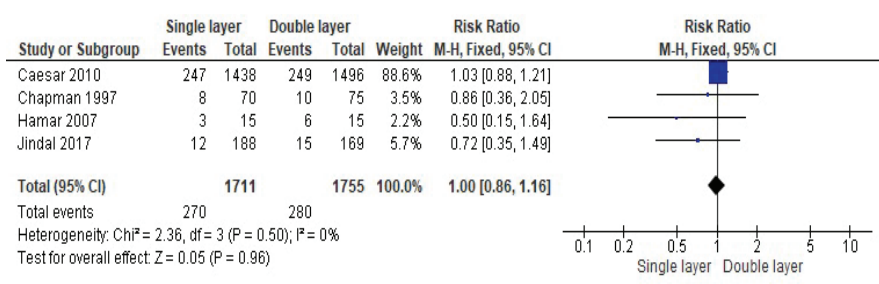

Supplementary Figure S3. The incidence of maternal infectious morbidity

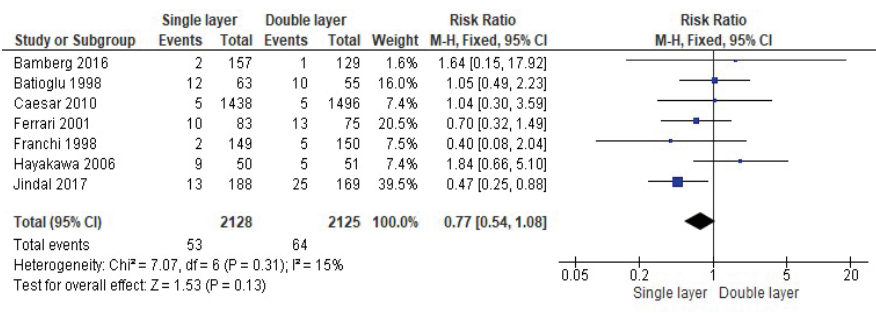

Supplementary Figure S4. The incidence of postpartum fever

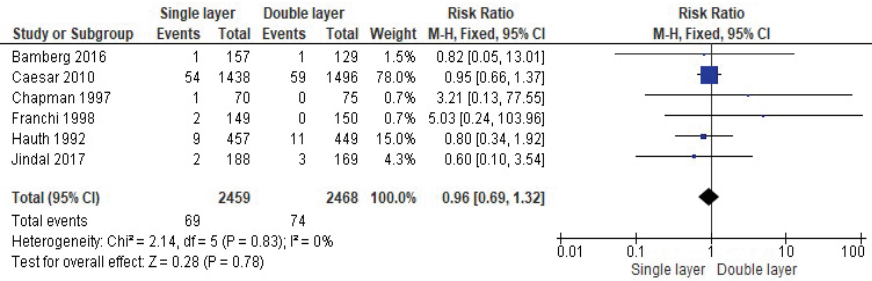

Supplementary Figure S5. Analysis of the number of patients needing blood transfusions

\begin{tabular}{|c|c|c|c|c|c|c|c|c|c|}
\hline \multirow[b]{2}{*}{ Study or Subgroup } & \multicolumn{2}{|c|}{ Single layer } & \multicolumn{2}{|c|}{ Double layer } & \multicolumn{2}{|r|}{ Risk Ratio } & & \multirow{2}{*}{$\begin{array}{c}\text { Risk Ratio } \\
\text { M-H, Fixed, 95\% CI }\end{array}$} & \\
\hline & Events & Total & Events & Total & Weight & M.H, Fixed, $95 \% \mathrm{Cl}$ & & & \\
\hline Batioglu 1998 & 3 & 63 & 3 & 55 & $2.3 \%$ & $0.87[0.18,4.15]$ & & & \\
\hline Caesar 2010 & 63 & 1438 & 62 & 1496 & $44.1 \%$ & $1.06[0.75,1.49]$ & & + & \\
\hline Chapman 1997 & 9 & 70 & 7 & 75 & $4.9 \%$ & $1.38[0.54,3.50]$ & & & \\
\hline Franchi 1998 & 0 & 149 & 1 & 150 & $1.1 \%$ & $0.34[0.01,8.17]$ & & & \\
\hline Hauth 1992 & 83 & 457 & 65 & 449 & $47.6 \%$ & $1.25[0.93,1.69]$ & & - & \\
\hline Total $(95 \% \mathrm{CI})$ & & 2177 & & 2225 & $100.0 \%$ & $1.15[0.93,1.43]$ & & $\bullet$ & \\
\hline Total events & 158 & & 138 & & & & & & \\
\hline $\begin{array}{l}\text { Heterogeneity: } \mathrm{Ch}^{2}= \\
\text { Test for overall effect }\end{array}$ & $\begin{array}{l}1.39, \mathrm{df}= \\
\mathrm{z}=1.31 \mathrm{if}\end{array}$ & $\begin{array}{l}4(P=0 \\
P=0.19\end{array}$ & $185) ; 1^{2}=0$ & & & & 0.02 & 0.1 & $\frac{1}{10}$ \\
\hline
\end{tabular}

Supplementary Figure S6. The incidence of endometriosis was a significant difference in RMT between the two groups $[\mathrm{MD}=-0.71(-1.31,-0.12)],(\mathrm{p}=0.02)$. The pooled analysis was heterogeneous ( $\mathrm{p}=0.01 ; \mathrm{I}^{2}=79 \%$ ) as seen in supplementary Figure S7A. We resolved the heterogeneity by excluding one study [El-Gharib et al.] ${ }^{(32)}(\mathrm{p}=0.17) ; \mathrm{I}^{2}=32 \%$. The pooled analysis after the exclusion still showed a significant difference in RMT between the two groups [MD=-0.43 $(-0.77,-0.09)],(\mathrm{p}=0.01)$ as seen in Supplementary Figure S7B. The RMT (in mm) at 6 weeks of the single-layer closure group was significantly less than that in the double-layer closure group.

\section{Incidence of Uterine Niche/Isthmocele at 6 Weeks:}

Nine studies $(21,27,30,34,38,41,42,44,45)$ reported the incidence of a uterine niche/isthmocele at 6 weeks as an outcome. The overall risk ratio showed that there was no significant difference in this outcome between the two groups $[R R=1.00(0.95,1.05)]$, $(p=0.93)$. The pooled analysis was homogeneous $(p=0.15$; $\left.\mathrm{I}^{2}=34 \%\right)$ as seen in Supplementary Figure S8.

\section{RMT (in mm) at 6-24 Months:}

The RMT (in mm) at 6-24 months was reported as an outcome by five studies ${ }^{(30,31,43-45)}$. The overall MD showed a significant difference in RMT between the two groups [MD $=-1.27(-2.28$, $-0.25]),(p=0.01)$. The pooled analysis was heterogeneous $\left(\mathrm{p}=0.01 ; \mathrm{I}^{2}=93 \%\right)$ as seen in Supplementary Figure S9. We could not solve the heterogeneity by subgroup analysis or the "leave-one-out" method. The RMT (in mm) at 6-24 months of the single-layer closure group was significantly less than the thickness of the double-layer closure group.

\section{Incidence of Uterine Niche/Isthmocele at 6-24 Months:}

The incidence of a uterine niche/Isthmocele at 6-24 months outcome was reported as an outcome by four studies ${ }^{(30,31,44,45)}$. The overall risk ratio showed no significant difference in this outcome between the two groups $[R R=1.19(0.89,1.60)]$, $(\mathrm{p}=0.24)$. The pooled analysis was heterogeneous $(\mathrm{p}=0.01$; $\left.\mathrm{I}^{2}=88 \%\right)$ as seen in Supplementary Figure S10A. We resolved the heterogeneity by the exclusion of one study [Kalem et al.] (28) $(\mathrm{p}=0.18) ; \mathrm{I}^{2}=41 \%$. The pooled analysis after the exclusion showed no significant difference between the two groups $[R R=$ $1.07(0.96,1.19)],(\mathrm{p}=0.23)$ as seen in Supplementary Figure S10B.

\section{Discussion}

In this meta-analysis, we included 8799 patients from 20 clinical trials. We found that the RMT in the double-layer closure group was significantly higher at 6 weeks follow-up and at 6-24 months follow-up compared to that in the single-layer group $(\mathrm{p}=0.01)$. Interestingly, there was also no significant difference in the incidence of uterine niche or isthmocele regardless of the closure used, at both postoperative 6 weeks and 6-24 months. There was also no significant difference between the two groups regarding the other measured outcomes: the need for additional suturing, the number of additional suture throws 
required, change in hemoglobin level, postoperative hematocrit level, maternal infectious mortality, postoperative endometritis, postpartum fever, or patients needing a blood transfusion.

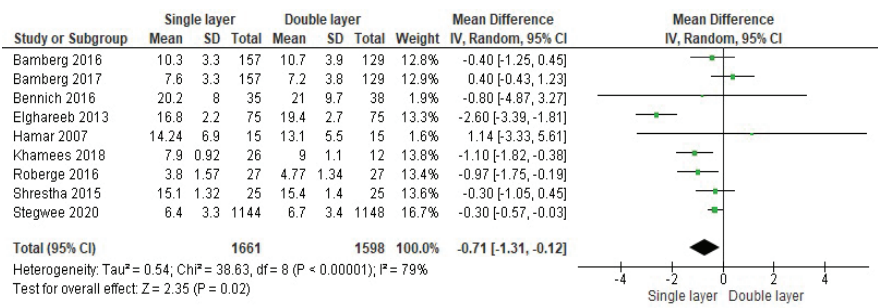

Supplementary Figure S7A. Analysis of residual myometrium thickness $(\mathrm{mm})$ at 6 weeks

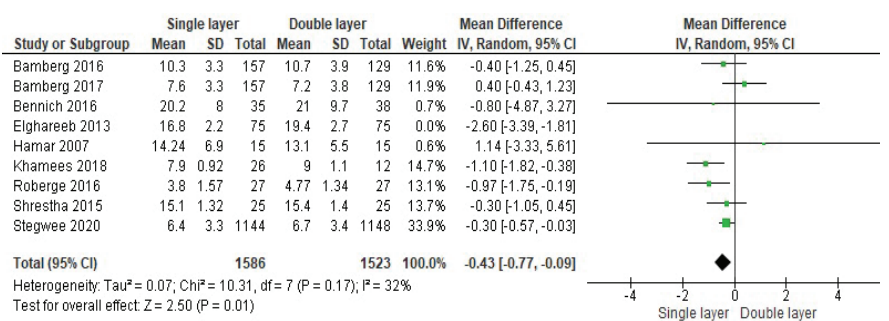

Supplementary Figure S7B. Analysis of residual myometrium thickness $(\mathrm{mm})$ at 6 weeks outcome

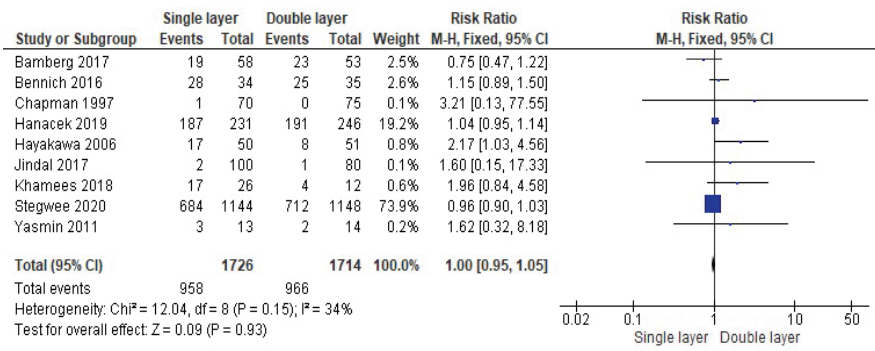

Supplementary Figure S8. Analysis of niche/isthmocele prevalence at 6 weeks

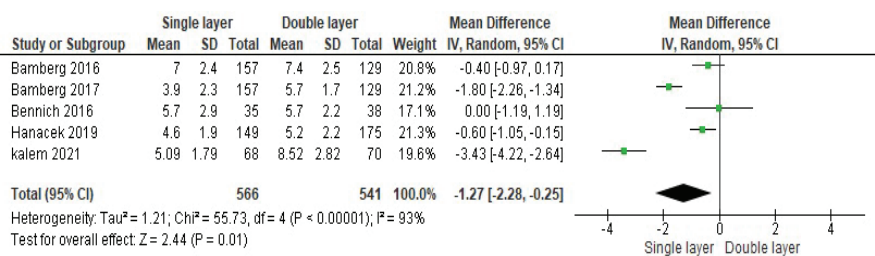

Supplementary Figure S9. Analysis of residual myometrium thickness (mm) at 6-24 months

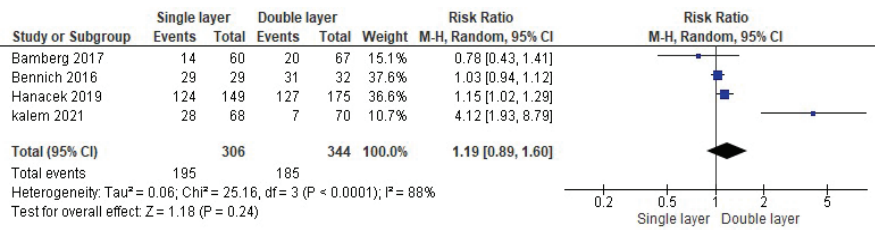

Supplementary Figure S10A. Analysis of niche prevalence at 6-24 months
Regarding recent meta-analyses on this topic, Stegwee et al. ${ }^{(39)}$ found that double-layer closure of the uterus was superior to single-layer closure as far as RMT and overall healing is concerned in their 2017 analysis, which is consistent with our results. Their study also found an overall decreased RMT with single-layer sutures, and a higher incidence of dysmenorrhea in the single-layer closure group. As with our analysis, isthmocele prevalence was the same in groups, as was the incidence of uterine dehiscence or rupture. Stegwee's meta-analysis included observational studies and was not limited to RCTs, and therefore they were able to include longer term outcomes such as incidence of uterine rupture with future pregnancies. Moreover, in their multicenter double-blinded RCT, conducted by the same authors two years later, Stegwee et al. ${ }^{(46)}$ reaffirmed the superiority of the double-layer closure over the singlelayer techniques regarding different outcomes. However, they found out that single-layer closure was associated with shorter operative time, lower isthmocele/niche prevalence, and reduced postoperative pain ${ }^{(44)}$.

Secondary to the limited availability of high-quality data on this topic, we could not address the association between a reduced RMT or isthmocele and future pregnancy complications. Other studies including lower quality data have attempted to answer this question. The majorities of these trials have concluded that the lower the RMT, the higher the risk of uterine scar defect, and this may be more pronounced in the presence of an isthmocele ${ }^{(10-12,44)}$. As stated, we did not have high-quality data to confirm or deny these findings.

Generally, an isthmocele is asymptomatic and is incidentally diagnosed. If symptomatic, however, it may manifest with abnormal uterine bleeding, postmenstrual spotting, dysmenorrhea, pelvic pain, and even infertility ${ }^{(9)}$. Treatment of an isthmocele, including medical and surgical treatments up to and including hysterectomy have been suggested by many authors, with no clear consensus in the literature ${ }^{(45,46)}$. Management with birth control pills, hysteroscopy, laparoscopy, vaginal procedures and hysterectomy have also been discussed ${ }^{(46,47)}$

\section{Strengths}

Our meta-analysis has many strong points. We conducted this study in strict adherence to the Cochrane handbook ${ }^{(25)}$. In addition, we included only randomized controlled trials and excluded all observational studies (especially retrospective designs). This ensured the strongest levels of evidence according

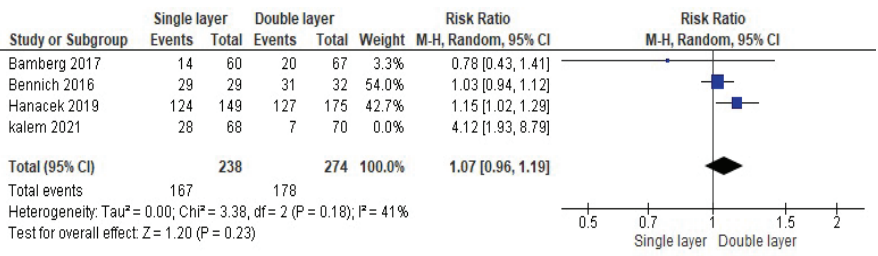

Supplementary Figure S10B. Analysis of niche prevalence at 6-24 months 
to the GRADE guidelines. Also, we tried to cover more than one follow-up period, which we feel gave more comprehensive evidence regarding clinical outcomes. In addition, this metaanalysis that we have completed in March of 2021, includes many late breaking clinical trials ${ }^{(27,28,30,38,47)}$; that have not yet been included in any other analysis, to the knowledge of our authors. Finally, the majority of studies we included showed a low $\mathrm{ROB}$ in nearly all the assessed domains.

\section{Study Limitations}

The major limitation was the lack of reported outcomes regarding long-term follow-up, particularly regarding future pregnancy outcomes and the incidence of uterine rupture. We sought that including the latest RCTs would provide sufficient data to analyze these outcomes. At this time this high-quality data on this topic from RCTs does not exist. The second weakness was a higher than expected heterogeneity in some of the reported outcomes. As a result, some outcomes could not be resolved by sensitivity analysis. This may affect the clinical application of the reported results. This is likely secondary to low sample, and relatively high dropout rates in some trials. We recommend further research on different techniques of uterine suturing and closure compared to RMT and isthmocele formation, and longterm follow-up relating to future pregnancy outcomes for these patients. We await the reexamination of these data when more evidence exists.

\section{Conclusion}

Double-layer closure showed higher RMT compared with single-layer closure. However, both closure techniques showed no significant difference regarding the incidence of uterine isthmocele (or niche) or other outcomes. Surgeons can predict higher RMT, but not a lower incidence of isthmocele if using a double-layer technique. High-quality data from RCTs regarding how lower RMT and isthmocele are associated to future pregnancy outcomes and the incidence of uterine rupture does not currently exist as we look forward to future RCTs on this subject.

\section{Ethics}

Peer-review: Externally peer-reviewed.

\section{Authorship Contributions}

Surgical and Medical Practices: G.J.M., A.M., A.K., S.R., G.B., H.U., J.P., A.A., C.C., S.G., A.C., K.S., Concept: G.J.M., A.M., A.K., S.R., G.B., H.U., J.P., A.A., C.C., S.G., A.C., K.S., Design: G.J.M., A.M., A.K., S.R., G.B., H.U., J.P., A.A., C.C., S.G., A.C., K.S., Data Collection or Processing: G.J.M., A.M., A.K., S.R., G.B., H.U., J.P., A.A., C.C., S.G., A.C., K.S., Analysis or Interpretation: G.J.M., A.M., A.K., S.R., G.B., H.U., J.P., A.A., C.C., S.G., A.C., K.S., Literature Search: G.J.M., A.M., A.K., S.R., G.B., H.U., J.P., A.A., C.C., S.G., A.C., K.S., Writing: G.J.M., A.M., A.K., S.R., G.B., H.U., J.P., A.A., C.C., S.G., A.C., K.S.
Conflict of Interest: No conflict of interest was declared by the authors.

Financial Disclosure: The authors declared that this study received no financial support.

\section{References}

1. Maskey S, Bajracharya M, Bhandari S. Prevalence of cesarean section and its indications in a tertiary care hospital. JNMA J Nepal Med Assoc 2019;57:70-3.

2. Betrán AP, Ye J, Moller AB, Zhang J, Gülmezoglu AM, Torloni MR. The increasing trend in caesarean section rates: global, regional and national estimates: 1990-2014. PLoS One 2016;11:e0148343. doi: 10.1371/journal.pone.0148343.

3. Ware K, King A, Sainz K, Marchand G. Salpingectomy at time of cesarean section without power device or suturing: A novel technique. Eur J Obstet Gynecol Reprod Biol 2019;234:e237. doi: 10.1016/j.ejogrb.2018.08.573

4. Marchand G, Masoud AT, Galitsky A, Azadi A, Ware K, Vallejo J, et al. Management of interstitial pregnancy in the era of laparoscopy: a meta-analysis of 855 case studies compared with traditional techniques. Obstet Gynecol Sci 2021;64:156-73.

5. Flamm BL, Goings JR, Liu Y, Wolde-Tsadik G. Elective repeat cesarean delivery versus trial of labor: A prospective multicenter study. Obstet Gynecol 1994:83:927-32.

6. Morris H. Surgical pathology of the lower uterine segment caesarean section scar: is the scar a source of clinical symptoms?. Int J Gynecol Pathol 1995; 14:16-20.

7. Vervoort AJMW, Uittenbogaard LB, Hehenkamp WJK, Brölmann HAM, Mol BWJ, Huirne JAF. Why do niches develop in Caesarean uterine scars? Hypotheses on the aetiology of niche development. Hum Reprod 2015;30:2695-702.

8. Naji O, Abdallah Y, Bij De Vaate AJ, Smith A, Pexsters A, Stalder C, et al. Standardized approach for imaging and measuring Cesarean section scars using ultrasonography. Ultrasound Obstet Gynecol 2012;39:252-9

9. Van Der Voet LF, Bij De Vaate AM, Veersema S, Brölmann HAM, Huirne JAF. Long-term complications of caesarean section. the niche in the scar: A prospective cohort study on niche prevalence and its relation to abnormal uterine bleeding. BJOG 2014;121:23644.

10. Rozenberg P, Goffinet F, Philippe HJ, Nisand I. Ultrasonographic measurement of lower uterine segment to assess risk of defects of scarred uterus. Lancet 1996;347:281-4.

11. Baranov A, Gunnarsson G, Salvesen K, Isberg PE, Vikhareva O. Assessment of Cesarean hysterotomy scar in non-pregnant women: reliability of transvaginal sonography with and without contrast enhancement. Ultrasound Obstet Gynecol 2016;47:499-505.

12. Naji O, Daemen A, Smith A, Abdallah Y, Saso S, Stalder C, et al. Changes in Cesarean section scar dimensions during pregnancy: a prospective longitudinal study. Ultrasound Obstet Gynecol 2013;41:556-62.

13. Bij De Vaate AJM, Van Der Voet LF, Naji O, Witmer M, Veersema $S$, Brölmann HAM, et al. Prevalence, potential risk factors for development and symptoms related to the presence of uterine niches following Cesarean section: systematic review. Ultrasound Obstet Gynecol 2014;43:372-82.

14. Vikhareva Osser O, Valentin L. Risk factors for incomplete healing of the uterine incision after caesarean section: General obstetrics. BJOG 2010;117:1119-26. 
15. Kaelin Agten A, Cali G, Monteagudo A, Oviedo J, Ramos J, TimorTritsch I. The clinical outcome of cesarean scar pregnancies implanted "on the scar" versus "in the niche." Am J Obstet Gynecol 2017;216:510.e1-6.

16. Pomorski M, Fuchs T, Zimmer M. Prediction of uterine dehiscence using ultrasonographic parameters of cesarean section scar in the nonpregnant uterus: A prospective observational study. BMC Pregnancy Childbirth 2014;14. 2021 Apr 1. doi: 10.1186/s12884014-0365-3

17. Roberge S, Demers S, Berghella V, Chaillet N, Moore L, Bujold E. Impact of single- vs double-layer closure on adverse outcomes and uterine scar defect: a systematic review and metaanalysis. Am J Obstet Gynecol 2014;211:453-60.

18. Hayakawa H, Itakura A, Mitsui T, Okada M, Suzuki M, Tamakoshi K, et al. Methods for myometrium closure and other factors impacting effects on cesarean section scars of the uterine segment detected by the ultrasonography. Acta Obstet Gynecol Scand 2006;85:429-34.

19. Yazicioglu F, Gökdogan A, Kelekci S, Aygün M, Savan K. Incomplete healing of the uterine incision after caesarean section: Is it preventable? Eur J Obstet Gynecol Reprod Biol 2006;124:32-6.

20. Durnwald C, Mercer B. Uterine rupture, perioperative and perinatal morbidity after single-layer and double-layer closure at cesarean delivery. Am J Obstet Gynecol 2003;189:925-9.

21. Moher D, Liberati A, Tetzlaff J, Altman DG; PRISMA Group. Preferred reporting items for systematic reviews and meta-analyses: the PRISMA statement. Ann Intern Med 2009;151:264-9, W64. doi: 10.7326/0003-4819-151-4-200908180-00135.

22. Cochrane Handbook for Systematic Reviews of Interventions. Cochrane Handbook for Systematic Reviews of Interventions. New York: John Wiley \& Sons; 2019.

23. Munder T, Barth J. Cochrane's risk of bias tool in the context of psychotherapy outcome research. Psychother Res 2018;28:347-55.

24. Jindal M, Gupta M, Goraya S, Tanjeet T, Matreja PS. Single layer versus double layer closure of uterus during caesarean section - a prospective study in index and subsequent pregnancy. Int Arch Biomed Clin Res 2017;3:3-7.

25. Ferraria AG, Frigerio LG, Candotti G, Buscaglia M, Petrone M, Taglioretti A, et al. Can Joel-Cohen incision and single layer reconstruction reduce cesarean section morbidity? Int J Gynaecol Obstet 2001;135-43.

26. Franchi M, Ghezzi F, Balestreri D, Beretta P, Maymon E, Miglierina $\mathrm{M}$, et al. A randomized clinical trial of two surgical techniques for cesarean section. Am J Perinatol 1998;15:589-94.

27. Hanacek J, Vojtech J, Urbankova I, Krcmar M, Křepelka P, Feyereisl J, et al. Ultrasound cesarean scar assessment one year post-partum in relation to one- or two-layer uterine suture closure. Acta Obstet Gynecol Scand 2020;99:69-78.

28. Kalem Z, Kaya AE, Bakırarar B, Basbug A, Kalem MN. An optimal uterine closure technique for better scar healing and avoiding isthmocele in cesarean section: a randomized controlled study. J Investig Surg 2021;34:148-56.

29. Brocklehurst P. Caesarean section surgical techniques: a randomised factorial trial (CAESAR). BJOG An Int J Obstet Gynaecol 2010;117:1366-76.

30. Batioğlu S, Kuşçu E, Duran EH, Haberal A. One-layer closure of low segment transverse uterine incision by the Lembert technique. J Gynecol Surg 1998;14:11-4.

31. Chapman SJ, Owen J, Hauth JC. One- versus two-layer closure of a low transverse cesarean: The next pregnancy. Obstet Gynecol 1997;89:16-8.
32. El-Gharib M, Awara A. Ultrasound evaluation of the uterine scar thickness after single versus double layer closure of transverse lower segment cesarean section. J Basic Clin Reprod Sci 2013;2:42.

33. Hamar BD, Saber SB, Cackovic M, Magloire LK, Pettker CM, AbdelRazeq SS, et al. Ultrasound Evaluation of the Uterine Scar After Cesarean Delivery. Obstet Gynecol 2007;110:808-13.

34. Hauth JC, Owen J, Davis RO. Transverse uterine incision closure: one versus two layers. Am J Obstet Gynecol 1992;167:1108-11.

35. E. Khamees R, H. Khedr A, Shaaban M, Bahi-Eldin M. Effect of single versus double layer suturing on healing of uterine scar after cesarean delivery. Suez Canal Univ Med J 2018;21:140-5.

36. Roberge S, Demers S, Girard M, Vikhareva O, Markey S, Chaillet $\mathrm{N}$, et al. Impact of uterine closure on residual myometrial thickness after cesarean: A randomized controlled trial. Am J Obstet Gynecol 2016;214:507.el-6.

37. Shrestha P, Shrestha S, Gyawali M. Ultrasound evaluation of uterine scar in primary caesarean section : a study of single versus double layer uterine closure. Am J Public Health Res 2015;3:178-81.

38. Yasmin S, Sadaf J, Fatima N. Impact of methods for uterine incision closure on repeat caesarean section scar of lower uterine segment. J Coll Physicians Surg Pakistan 2011;21:522-6.

39. Stegwee SI, van der Voet LF, Ben AJ, de Leeuw RA, van de Ven PM, Duijnhoven RG, et al. effect of single- versus double-layer uterine closure during caesarean section on postmenstrual spotting (2Close): multicentre, double-blind, randomised controlled superiority trial. BJOG 2021;128:866-78.

40. Bamberg C, Dudenhausen JW, Bujak V, Rodekamp E, Brauer M, Hinkson L, et al. A prospective randomized clinical trial of single vs. double layer closure of hysterotomy at the time of cesarean delivery: The effect on uterine scar thickness. Ultraschall Med 2018;39:34351.

41. Palareti G, Legnani C, Cosmi B, Antonucci E, Erba N, Poli D, et al. comparison between different D-Dimer cutoff values to assess the individual risk of recurrent venous thromboembolism: Analysis of results obtained in the DULCIS study. Int J Lab Hematol 2016;38:42-9

42. Tahara M, Shimizu T, Shimoura H. Preliminary report of treatment with oral contraceptive pills for intermenstrual vaginal bleeding secondary to a cesarean section scar. Fertil Steril 2006;86:477-9.

43. Gubbini G, Casadio P, Marra E. Resectoscopic correction of the "isthmocele" in women with postmenstrual abnormal uterine bleeding and secondary infertility. J Minim Invasive Gynecol 2008; 15:172-5.

44. Florio P, Gubbini G, Marra E, Dores D, Nascetti D, Bruni L, et al. A retrospective case-control study comparing hysteroscopic resection versus hormonal modulation in treating menstrual disorders due to isthmocele. Gynecol Endocrinol 2011;27:434-8.

45. Bennich G, Rudnicki M, Wilken-Jensen C, Lousen T, Lassen PD, Wøjdemann K. Impact of adding a second layer to a single unlocked closure of a Cesarean uterine incision: Randomized controlled trial. Ultrasound Obstet Gynecol 2016;47:417-22.

46. Stegwee SI, Jordans IPM, van der Voet LF, van de Ven PM, Ket JCF, Lambalk CB, et al. Uterine caesarean closure techniques affect ultrasound findings and maternal outcomes: a systematic review and meta-analysis. BJOG 2018;125:1097-108.

47. Stegwee S, Voet L, Ben A, Leeuw R, Ven P, Duijnhoven R, et al. Effect of single- versus double-layer uterine closure during caesarean section on postmenstrual spotting (2Close): multicentre, doubleblind, randomised controlled superiority trial. BJOG 2021128:86678 . 
Supplementary Table S1. Risk of bias assessment

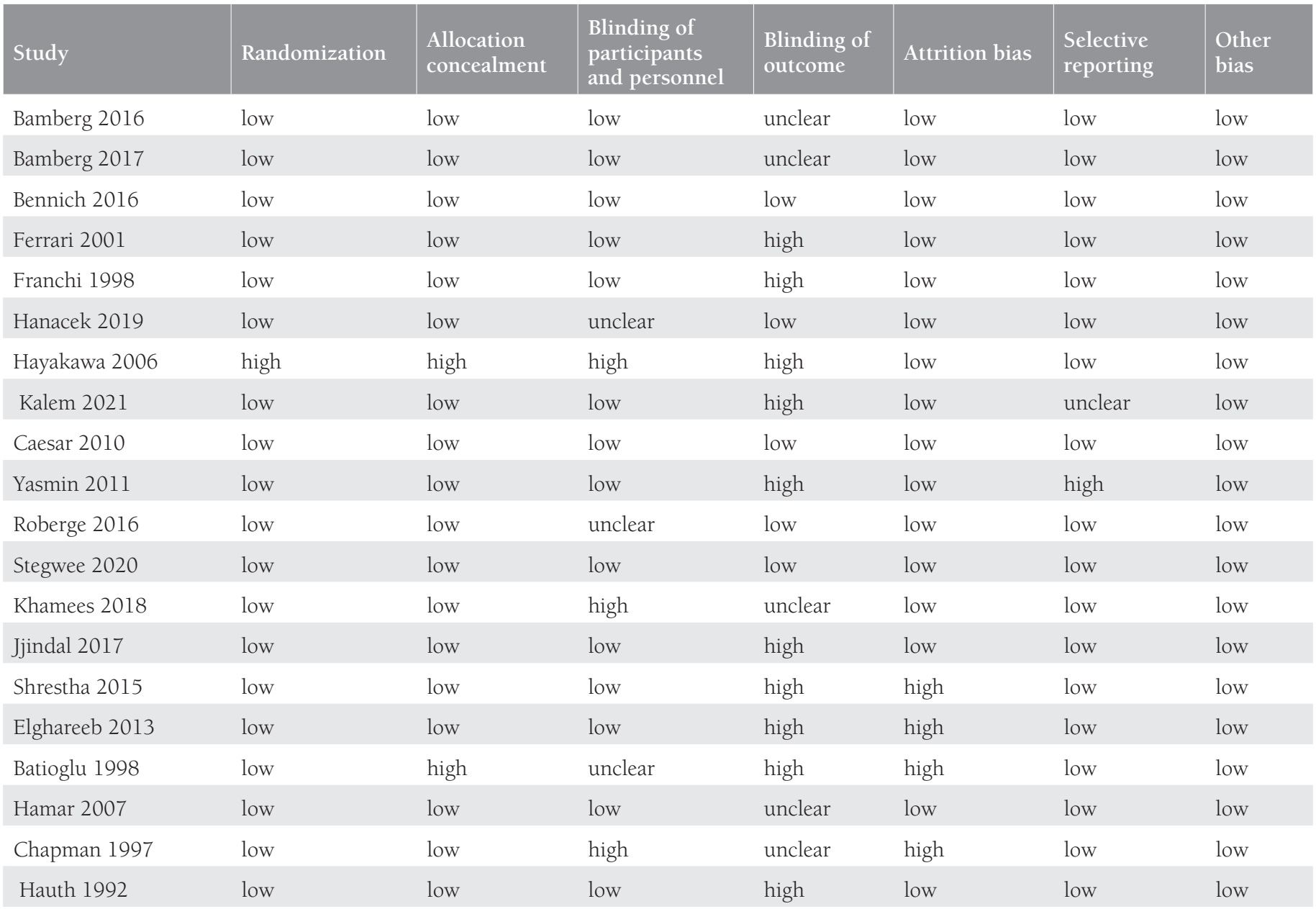

